UDC: 821.111.09-31 Вулф В.; 305:821.09

\title{
THE MOBILITY OF SEXUAL IDENTITY AND THE ANDROGYNOUS VISION IN VIRGINIA WOOLF'S ORLANDO
}

\begin{abstract}
NINA SIRKOVIĆ 1
University of Split,

Faculty of Electrical Engineering, Mechanical Engineering and Naval Architecture, Department of General Courses,

Split, Croatia
\end{abstract}

\begin{abstract}
Suvremeni koncept identiteta obuhvaća fluidne i dinamične odnose između pojedinca i političkog, društvenog i kulturnog okruženja u kojem se on nalazi. Budući da se zbog utjecaja putovanja, nomadizma, dijaspore, kulturne hibridnosti i sličnih društvenih kretanja granice pomiču sve dalje, javljaju se potpuno nove konfiguracije identiteta. Kako se "nova geografija identiteta" i rod kao jedna od njenih sastavnica uklapaju u androginu viziju u romanu Orlando Virginije Woolf? Mobilnost spolnih identiteta likova iz romana, te kolebanje između dva spola postavljaju zahtjev za preispitivanjem ne samo određenosti spolnih razlika i njihovih međusobnih odnosa, nego i same stvarnosti u kojoj živimo.
\end{abstract}

Ključne riječi: Virginia Woolf, Orlando, Vlastita soba, identitet, rod, androginija.

Orlando, a novel which was in the beginning meant to be "a writer's holiday" (Woolf 1978, 2: 134) is in many aspects different from the rest of of Virginia Woolf's work. The novel is dedicated to Vita Sackwille-West and Woolf's first intention was to describe a portrait of Vita as Orlando, a young nobleman. The satiric tone of the novel, plenty of fictional and fantastic, even grotesque events and descriptions, together with playing with historic time (in 350 historic years Orlando only grows 20 years older), make it difficult to answer the question: What kind of a novel is Orlando?

Despite bearing the subtitle of "A Biography", it is far from being a classical biography. The novel contains both biographical and autobiographical elements. Orlando was inspired not only by Vita and her ancestry, but also by her family estate Knole, which was as much the inspiration as Vita was herself. The novel is sometimes considered as a parody of a biography (Lee 1999: 515), as well as a fantasy-biography (Topping Bazin 1973: 139), a novel about writers (Pomeroy 1978: 506), the largest and

1 Kontakt podaci (Email): nina.sirkovic@fesb.hr 
most charming love letter in literature (Nicholson 1993: 9), and even as a biographical novel about an androgynous creature (Nathan 1964: 102).

Orlando is a character who must first discover himself to be able to create art and through this process and more than three hundred years of experience he changes his sex - a young nobleman becomes a woman poet. This fact helped Woolf to talk about two important matters: the problem of gender and a new concept of identity, two issues which later became crucial for feminist research.

The story about clothes is actually the story about gender. From their birth, people are determined by their clothes, and they are expected to act in the way appropriate to their sex. Clothes determine both the way a person looks at the world and the way $s /$ he acts, according to her/his points of view. But the clothes can be deceptive too; they become just a symbol for something that is hidden beneath. When he was already a woman, Orlando used to disguise as a man, first as a gypsy, and later as a nobleman. Speaking of clothes, the biographer ironically mentions they have more important function than just to keep us warm. They change our view of the world and the world's view of us. Sometimes, it seems that the clothes wear us and not we them - we can wear the clothes of one sex and can disguise the other sex underneath. The attitudes of men and women towards life are completely different: the man looks the world right in the face, "as if it were made for his uses and fashioned to his liking" (Woolf 2003: 92). The woman takes a sidelong glance at the world, full of subtlety and suspicion. The question is, if they had worn the same clothes, would they have had the same outlooks?

Modern theories have proven that different race, gender and sexuality, as well as social, political, cultural and other specific backgrounds influence the concept of identity. New geographies of identity insist on dissolving the boundaries due to movement, travel, nomadism, diaspora, cultural hybridity etc. so the new configuration of identity can take place. ${ }^{2}$ Identity is multiple, contradictory, situational, relational and fluid. The term identity consists of a double meaning: it denotes something which is specific, different from the other, but at the same time, it also denotes sameness, belonging to a group, a kind of commonality (as in the word identical) (Stanford Friedman 1999: 19). Orlando is a romantic hero who travels through centuries. First he is a man, but becomes a woman. He is a nobleman in the curt, but prefers the company of lower cases. He experiences love with exotic Russian woman, spends some time in the oriental world with Turks, joins gypsies, travels with them and finally settles at home again. He falls and rises and proceeds on his way guided by his supernatural gift, charm, wit, curiosity and love for life itself.

The central event in the novel is Orlando's transformation from man to a woman. But, in the end we have to ask ourselves: What is Orlando? Is she the young nobleman, the Turkish ambassador, the gypsy, the affirmed poet? What is her real identity? The mobility of Orlando's sexual identity, as well as of other characters' in the novel destroys

2 Susan Standford Friedman, who coined term, argues that "the new geography of identity" stresses the interaction of gender with other forms of power relations based on cultural categories such as: race, class, sexuality, religion, ethnicity, age, etc. This kind of geography is dynamic and moves through socially constructed spaces. It performs a kind of dialectic that reflects opposing movements in the world today, revolving around the issue of identity. S. Stanford Friedman, Mappings: Feminism and the Cultural Geographies of Encounter. Princeton University Press, New York, 1999. 
the idea of a single, unitary identity. Each character has male and female components in his/her identity. The greatest vacillation of sex occurs in Orlando, who, after she had changed sex, still continued to disguise herself. A woman who lived for thirty years of her life as a man and assimilated all the experiences from both sexes, succeeded in escaping from the traditional polarities of sexual classifications and stereotypes of society. The ambiguities of gender and sexuality have lead to an intermixture of identities. The character of Orlando is an intermix between masculine and feminine, heterosexual and homosexual, English and foreign, "civilised" and "savage" (Kaivola 1999: 254). This meeting of differences can be interpreted from the viewpoint of modern theories of identity, which appeared almost seventy years after the novel was written.

Orlando is a young nobleman in Queen Elisabeth's court. The very first sentence of the novel: "He - for there could be no doubt of his sex, though the fashion of the time did something to disguise it - was in the act of slicing at the head of a Moor which swung from the rafters" (Woolf 2003: 5) invites the reader to doubt that there is something hidden beneath this immature, but typically masculine action, as well as beneath the clothes which apparently hide his maleness. The appearance and the action do not go together; there is certain ambiguity about Orlando's character from the very beginning. His outer looks are also a kind of a mixture of male and female characteristics: "The long, curled hair, the dark head bent so reverently, so innocently before her, implied a pair of the finest legs that a young nobleman has ever stood upright upon; and violet eyes; and a heart of gold, and loyalty and manly charm" ( Woolf 2003: 10). He looked shy and innocent, and "there was a serenity about him always which had the look of innocence when, technically, the word was no longer applicable" (Woolf 2003: 11). But his appearance was deceptive, because, after he had fallen in love for the first time, he recollected his previous lovers: "Whom had he loved, what had he loved, he asked himself in a tumult of emotion, until now? An old woman, he answered all skin and bone. Red-cheek trulls too many to mention. A pulling nun. A hard-bitten cruelmouthed adventuress" (Woolf 2003: 18). Orlando was anarchic and socially unsettling, but his love for Russian princess Sasha changed his point of view forever; he was happy as never before. After she left him, he was desperate, full of rage and swore at her in a typically manly way:"... he hurled at the faithless woman all the insults that have ever been the lot of her sex. Faithless, mutable, fickle, he called her; devil, adulteress, deceiver" (Woolf 2003: 30).

After this great disappointment Orlando falls into a trance-like seven day sleep after which he turns to reading books, trying to forget his sorrow and solitude, and, unlike men at that time, he turned again to writing, which was considered "an inexpiable disgrace" (Woolf 2003: 37) for a nobleman. He had a kind of "glamour" (Woolf 2003: 60 ), a kind of rare gift, beside his power made of beauty and birth. But despite all this, Orlando felt empty and unhappy. The episode with the Archduchess Harriet, who turned out later to be the Archduke Harry, made him flee from England to Constantinople.

As the ambassador in Turkey, Orlando enchanted people there too. He became "the adored of women and some men" (Woolf 2003: 61), but the tedious protocols and boring diplomatist's duties and conversations made him even more depressed than before. He preferred dining with his dogs, talking to them in English. Sometimes he used to sneak out disguised and mingled with the crowd, strolled through the bazaars, 
or even went to the mosque. He suddenly fell into seven-day sleep again and woke the day when the Turks rose against the Sultan and set fire to the town. He stretched himself, rose, and looked at himself in the mirror and discovered that he was a woman. The strange, sudden and unexpected change of Orlando's sex at the age of thirty strikes the reader, but it did not strike Orlando who does not show any surprise:

Orlando had becomea woman there is no denying it. But in every other respect, Orlando remained precisely as he had been. The change of sex, though it altered their future, did nothing whatever to alter their identity. Their faces remained, as their portraits prove, practically the same. His memory - but in future we must, for convention's sake, say 'her' for 'his', and 'she' for 'he' - her memory then, went back through all the events of her past without the encountering any obstacle. (Woolf 2003: 67)

The narrator simply slips from the pronoun 'he' over 'they' (meaning both sexes) to 'she'. For a short time, there were two persons contained in one identity, but the next moment he speaks of one person again. Although it seemed in the beginning that Orlando remained the same, the changes happened gradually. After he had become a woman and was regarded as such, she experienced different attitudes and expectations towards her as a woman. She remembered her own insistence on women being obedient, chaste, scented and dressed neatly and felt as trapped in her own stereotypes. She was not definitely sure of her sex; she censured them both equally, since she belonged to both of them and knew the secrets and weaknesses of each. It was a difficult state of mind to be in, since "the comfort of ignorance seemed utterly denied to her" (Woolf 2003: 77).

After returning to England again, Orlando had problems in being accepted as a woman, but, after it was legally proved, she could inherit her own house and continue living as a woman. But as a woman, she continued liking women as she did before, "and if the consciousness of being of he same sex had any effect at all, it was to quicken and deepen those feelings which she had as a man" (Woolf 2003: 79). In a way, Orlando calmed down, became wiser and less impulsive. She lost some illusions and developed a spirit capable of resistance. She lived more peacefully, but never fully accepted that she was a woman; she still sometimes reacted like a man who thinks of women as nuisances.

Feeling that the life had escaped her, Orlando started to go out at night again. This time she found clothes she had worn when she was a nobleman and went out disguised. She joined the company of prostitutes, who at the beginning roused in her all the feelings of a man, but after she admitted herself to being a woman, she enjoyed female company. As a man, Orlando loved women, but as a woman, she enjoyed the love of both sexes. When she married the seaman and adventurer Marmaduke Bonthorp Shelmerdine and by the way becomes mother of a boy, her feelings for her former lover Sasha arise again, when she meets her in a department store. Although Sasha is fat and lethargic now, she retrieves old memories and emotions within Orlando.

Because Orlando gathered within herself all the male and female experiences, she was exquisitely skilled in many things, she knew more about crops than any famer, she could drink with the best, liked games of hazard and rode well. She was a real hero. On the other hand, she could burst into tears upon the slightest provocation. Like most women, 
she did not know much about geography, mathematics, and to travel south meant to her to travel downhill. The biographer concludes: "Whether, then, Orlando was most man or a woman, it's difficult to say and cannot now be decided" (Woolf 2003: 93). The truth about Orlando and his/her identity is explained in the form of a dilemma: "Different though the sexes are, they intermix. In every human being a vacillation from one sex to the other takes place, and often it is only the clothes that keep the male or female likeness, while underneath the sex is the very opposite of what it is above. (Woolf 2003: 93)

Makiko Minow-Pinkney (1987: 128-129) points at the incident in the book which best reveals that sex is not a nature, but a social product: as soon as Orlando, as a woman returns to England, her sex comes under legal deliberation. "Thus it was a highly ambiguous condition, uncertain whether she was alive or dead, man or woman, Duke or nonentity" (Woolf 2003: 125). After a hundred years, the lawsuit is settled, Orlando's sex is pronounced female and Orlando's womanhood was admitted by the court. Consequently, she gained possession of her title, her estate and the house, but the judgement does not admit female descendants hereafter. The impression is that Orlando got such a favourable verdict just in order to avoid the property falling into hands of three gypsy sons of Rosina Pepita whom Orlando allegedly married while working as ambassador in Turkey. In any case, womanhood is removed from the possibility of gaining any inheritance.

Orlando vacillates between two sexes; after he had become a woman, she still disguised herself in male clothing. The other characters also show a kind of uncertainty about their sex. When Orlando sees Sasha (whose name can also be female as well as male) for the first time, he is not sure if it is a boy or a woman:

(...) he beheld, coming from the pavilion of the Muscovite Embassy, a figure, which, whether boy's or woman's, for the loose tunic and trousers of the Russian fashion served to disguise the sex, filled him with the highest curiosity. The person, whatever he name or sex, was about middle height...(...) When the boy, for alas, a boy it must be - no woman could skate with such speed and vigour - swept almost on tiptoe past him, Orlando was ready to tear his hair with vexation that the person was of his sex...(...) But the skater came closer. Legs, hands, carriage were a boy's, but no boy ever had a mouth like that; no boy had those breasts... (...) She was a woman. (Woolf 2003: 17)

Sasha turned out to be a woman, but, just as her sex was deceptive in the beginning, her character was also more man like. She was passionate, uncompromising, daring, free and exotic, so much different from other women in the court. This extravagant person became the love of Orlando's life.

Concealment of sex and disguise are the essence of Orlando's relationship with the Archduchess Harriet. This tall, ugly woman who resembled a hare, startled, but obdurate, had a lot of male characteristics: she could ride well and showed great taste in wines and knew much about firearms. When Orlando was a young nobleman, she occupied him so much, that he had to escape far away to Turkey just to get away from her. Later,

3 See Minow-Pinkney (1987: 133-134). 
when Orlando returned to England as a woman, Archduchess Harriet appeared again. When Orlando turned to the Archduchess to offer her some wine, she beheld "... Iin her place stood a tall gentleman in black. A heap of clothes lay in the fender. She was alone with a man" (Woolf 2003: 17).

The Archduke revealed himself as a man, who he had always been, but seeing young Orlando as a nobleman, fell so deeply in love wit him, that he tried to seduce him disguised in a woman. Now, when Orlando was a woman, his love remained the same, and he tried again (unsuccessfully) to win her heart. Clothes again serve both to conceive and reveal a person's sex.

The marriage of Orlando and Shell, the relationship which is permeated through friendship and a deep mutual understanding is a bond between two similar ambiguous creatures. The most intense moment of their relation occurs when they recognize the reversed sex in each other:

"You're a woman, Shell!" she cried.

"You're a man, Orlando!" he cried.

Never was there such a scene of protestation and demonstration as then took place since the world began. (Woolf 2003: 124)

Throughout the whole novel, Orlando represents an intermix of alternating genders. She is an androgynous creature, but her character does not consist of both sexes - she is in constant change; either s/he changes sex, or pretends to. Orlando vacillates from one sex to another and shows that feminity is an inherently unstable position, or, as it consists of putting on and off the identities either of one or the other sex. (Bowlby 1997: 51) The idea of an androgynous creature which will assimilate all the male and female characteristics in a single person does not function in the case of Orlando. Woolf's androgynous vision represented in A Room of One's Own, where a person should be woman-manly or man-womanly, is not the same as in Orlando.

Woolf's idea of a man and a woman getting together into the taxi reflects the romantic idea of the fusion of two sexes in order to get the unity of mind. Tracing the originally Coleridge's idea of an androgynous mind, Woolf explains her vision of a mind which is incandescent, unimpeded and free from all the prejudices, grievance and anger. Our mind often changes its focus, bringing the world into different perspectives. Women sometimes experience a splitting off of consciousness, which can be rather uncomfortable. Woolf tries to find a state of mind in which nothing should be held back. Through the scene of a man and a woman getting into the taxi together, the mind, which was divided in two, has come together in a natural fusion. An androgynous mind is formed, after it has absorbed all the male and female experiences together. The mind acquires then a harmonious balance between male and female elements. Woolf mentions Shakespeare as an example of an androgynous mind. An artist should avoid the notion of his/her sex. As the narrator in A Room of One's Own says, "it is fatal to be a man or a woman pure and simple; one must be woman- manly or man-womanly" (Woolf 1998: 136). ${ }^{4}$

4 Woolf's idea of androgyny caused disputes among critics. E. Showalter argued that the idea of an androgynous mind was a way of Woolf's own escaping from herself (see E. Showalter, A Literature of Their Own, the chapter "Virginia Woolf and the Flight into Androgyny" and Toril Moi's answer to her in the essay "Who's Afraid of Virginia Woolf?" in SexualTtextual Politics: Feminist Literary Theory), Nancy Topping Bazin wrote about the idea of androgyny, which is present in all Woolf's novels in Virginia Woolf and the Androgynous Vision. 
In Orlando there is no fusion of opposites, hence, there is no androgynous mind. Orlando's character subsequently becomes androgynous, but there is never balance and harmony either in her mind, or in her heart. The gender distinctions are still present, even as they intermix. In A Room of one's Own there are two bodies which form one mind, whereas in Orlando there is one body, but there is no unity of mind. The intermixture of alternating genders does not mean fusion into homogenous unity; when Orlando slides from man to woman, there is no unique image of her personality. She is aware of the many 'selves' that a person consists of. Speaking of possible 'selves' of Orlando, the biographer says:

Choosing then, only these selves we have found room for, Orlando may now have called on the boy who cut the nigger's head down; the boy who strung it up again; the boy who sat on the hill; the boy who saw the poet; the boy who handed the Queen the bowl of rose water; or she may have called upon a young man who fell in love with Sasha; or upon the Courtier; or upon the Ambassador; or upon the Soldier; or upon the Traveller; or she may have wanted the woman to come to her; the Gipsy; the Fine Lady, the Hermit; the girl in love with life; the Patroness of Letters...(...)...all may different and she might have called upon any of them. (Woolf 2003: 153)

All these identities are parts of the answer to question: What is Orlando? The opinion that Woolf did not offer the idea of androgyny as a solution, but as rather as an ideal seems to offer an answer. Speaking of two different kinds of androgyny in A Room of One's Own and Orlando Karen Kaivola (1999: 257) stresses the social and historical situation at the time both works were written. Under the threat of incoming fascism, Woolf tried to put forth an ideal of human unity in A Room of One's Own, whereas in Orlando there is incitement to greater social and sexual freedom. Both visions are utopian, but Orlando is a fantasy novel, which started as a joke and involuntarily became serious. Orlando is fluid and dynamic, and its androgyny is active, mobile, and unstable; it is a demonstration of the groundlessness of existing differences and the proof of multiple selves.

\section{REFERENCES}

Bowlby, R. 1997. Feminist Destinations and Further Essays on Virginia Woolf. Edinburg: Edinburgh University Press, 43-53, 149-172.

Kaivola, K. 1999. Revisiting Woolf's Representations of Androginy: Gender, Race, Sexuality and Nation. Tulsa Studies in Women Literature 18/2, 236-263.

Lee, H. 1999. Virginia Woolf. New York: Vintage Books.

Minow-Pinkley, M. 1987. Virginia Woolf and the Problem of the Subject. Brighton: The Harvester Press.

Natan, M. 1964. Virdžinija Vulf njom samom, prev. J. Jelić. Beograd: Savremena škola. Nicolson, N. (ed.) 1992. Vita and Harold. The Letters of Vita Sackville-West and Harold Nicolson 1910-1926. London: Weidenfeld and Nicolson. 
Pomeroy, E. W. 1978. Garden and Wilderness: Virginia Woolf reads the Elizabethans. Modern Fiction Studies 24/4, 497-508.

Stanford Friedman, S. 1999. Mappings: Feminism and the Cultural Geographies of Encounter. New York: Princeton University Press.

Woolf, V. 1978. The Diary of Virginia Woolf, III vol., ed. by A. 0. Bell. London: The Hogarth Press.

Woolf, V. 2003.Orlando, a Biography. Ware: Wordsworth Classics.

\section{SUMMARY}

\section{ORLANDO: THE MOBILITY OF SEXUAL IDENTITY AND THE ANDROGYNOUS VISION}

The modern concept of identity implies fluid and dynamic relations between an individual and political, social, cultural and other specific backgrounds. As the boundaries tend to dissolve due to travel, nomadism, diaspora, cultural hybridity etc. the new configurations of identity take place. How do the "new geography of identity", and gender as one of its constituents fit in the androgynous vision of Virginia Woolf, presented in her novel Orlando? The mobility of sexual identities of the characters in the novel and the vacillation between one sex and the other raise issues not only of the determinability of sexual difference and the relationship between masculine/feminine, but also of the reality of life itself.

KEYWORDS: Virginia Woolf, Orlando, A Room of One's Own, identity, sexual vacillations, gender, androgyny.

(Original scientific paper received 20.10.2010; revised 04.07.2011; accepted 01.12.2011) 